\title{
Tenascin-C and mechanotransduction in the development and diseases of cardiovascular system
}

\author{
Kyoko Imanaka-Yoshida ${ }^{1,2 *}$ and Hiroki Aoki ${ }^{3}$ \\ ' Department of Pathology and Matrix Biology, Mie University Graduate School of Medicine, Tsu, Japan \\ ${ }^{2}$ Mie University Research Center for Matrix Biology, Tsu, Japan \\ ${ }^{3}$ Cardiovascular Research Institute, Kurume University, Kurume, Japan
}

\section{Edited by:}

Kersti K. Linask, University of South

Florida Morsani College of

Medicine, USA

Michiko Watanabe, Case Western

Reserve University School of

Medicine, USA

\section{Reviewed by:}

Richard L. Goodwin, University of South Carolina School of Medicine, USA

Raymond Bruce Runyan, University of Arizona, USA

*Correspondence:

Kyoko Imanaka-Yoshida, Department of Pathology and Matrix Biology,

Mie University Graduate School of

Medicine, 2-174 Edobashi,

Tsu 514-8507, Japan

e-mail:imanaka@

doc.medic.mie-u.ac.jp
Living tissue is composed of cells and extracellular matrix (ECM). In the heart and blood vessels, which are constantly subjected to mechanical stress, ECM molecules form well-developed fibrous frameworks to maintain tissue structure. ECM is also important for biological signaling, which influences various cellular functions in embryonic development, and physiological/pathological responses to extrinsic stimuli. Among ECM molecules, increased attention has been focused on matricellular proteins. Matricellular proteins are a growing group of non-structural ECM proteins highly up-regulated at active tissue remodeling, serving as biological mediators. Tenascin-C (TNC) is a typical matricellular protein, which is highly expressed during embryonic development, wound healing, inflammation, and cancer invasion. The expression is tightly regulated, dependent on the microenvironment, including various growth factors, cytokines, and mechanical stress. In the heart, TNC appears in a spatiotemporal-restricted manner during early stages of development, sparsely detected in normal adults, but transiently re-expressed at restricted sites associated with tissue injury and inflammation. Similarly, in the vascular system, TNC is strongly up-regulated during embryonic development and under pathological conditions with an increase in hemodynamic stress. Despite its intriguing expression pattern, cardiovascular system develops normally in TNC knockout mice. However, deletion of TNC causes acute aortic dissection (AAD) under strong mechanical and humoral stress. Accumulating reports suggest that TNC may modulate the inflammatory response and contribute to elasticity of the tissue, so that it may protect cardiovascular tissue from destructive stress responses. TNC may be a key molecule to control cellular activity during development, adaptation, or pathological tissue remodeling.

Keywords: extracellular matrix, tenascin-C, matricellular protein, mechanotrasduction, coronary artery, heart, aortic dissection

\section{INTRODUCTION}

Living tissue is composed of cells and extracellular matrix (ECM). In the heart and blood vessels, which are constantly subjected to mechanical stress, ECM molecules form well-developed fibrous frameworks to maintain the tissue structure by supporting the shape and position of cells, integrating and transmitting mechanical forces generated inside the cells to whole tissue. ECM is also important for biological signaling, which influences various cellular functions in embryonic development, and physiologi$\mathrm{cal} /$ pathological responses to extrinsic stimuli. Tenascin-C (TNC) is a non-structural ECM protein highly expressed in morphogenesis and tissue remodeling, and has a wide range of effects on cell responses. Emerging evidence suggests that TNC may be involved in mechanotransduction in response to mechanical stress. In this review, we will focus on the adaptive role of TNC in the mechanical stress response in the development and pathological state of the cardiovascular system.

\section{OVERVIEW OF EXTRACELLULAR MATRIX IN CARDIOVASCULAR SYSTEM FIBROUS EXTRACELLULAR MATRIX}

Of all the organs of the body, the large arteries, particularly the aorta, are subject to the greatest mechanical stress. They have a well-organized fibrous framework. In the tunica media, multilayered elastin sheets (lamellae) connected by fine elastin fibers form a three-dimensional continuous network that links smooth muscle cells. This elastin network of the arterial wall functions as an elastic reservoir protecting the tissue from destructive stress. The outermost layer, the tunica adventitia, consists of a collagenrich ECM and helps prevent vascular rupture at extremely high pressures (Wagenseil and Mecham, 2009). In the heart, the major structural component of the ECM is collagen, which also forms a three-dimensional network interconnecting myocytes to each other and to the vasculature (Caulfield and Borg, 1979; Borg and Caulfield, 1981). The fibrous skeleton composed of collagen is 
continuous with the annulus fibrosus cordis, the support apparatus of the tricuspid, mitral, and aortic valves to the cardiac muscle in a manner analogous to the attachment of tendons to skeletal muscle (Hinton and Yutzey, 2011). This stress-tolerant collagenous network not only contributes to passive elastic properties of the heart but also to the transmission of mechanical forces to and from the cardiomyocytes (reviewed in Sussman et al., 2002; Bowers et al., 2010; Borg and Baudino, 2011).

\section{NON-STRUCTURAL MATRIX, MATRICELLULAR PROTEIN}

In addition to the fibrous ECM, a unique functional category of non-structural ECM, matricellular proteins, are receiving increasing attention (Bornstein, 2009). Matricellular proteins constitute a growing family (Table 1 ) that originally included thrombosondin-1 (TSP1), SPARC (secreted protein, acid and rich in cysteine; osteonectin), and TNC (Sage and Bornstein, 1991), and then TSP2, osteopontin, CCN1, CTGF (CCN2), and tenascin-X were added (Bornstein and Sage, 2002). They have common unique properties: (1) expressed at high levels during development and in response to injury; (2) do not subserve structural roles but function as modulators of cell-matrix interactions; (3) bind to many cell-surface receptors, other ECM molecules, growth factors, cytokines, and proteases; (4) generally induce de-adhesion, in contrast to the positive adhesivity of most matrix proteins (Bornstein and Sage, 2002). The term has become used more widely and new members, such as galectins and periostin, have joined the group (Bornstein, 2009). In cardiovascular development, significant roles of periostin have been reported (Conway and Molkentin, 2008; Inai et al., 2008; Norris et al., 2008, 2009; Ghatak et al., 2014). It is also noteworthy that some members, such as SPARC, osteopontin, and periostin, have been found to be related to developing

\section{Table 1 | Matricellular proteins.}

Thrombospondins
TSP-1
TSP-2
Secreted protein acidic and rich in cysteine (SPARC/osteonectin)
Tenascin family
Tenascin-C
Tenascin- $\mathrm{X}$
Osteopontin
CCN family
CCN1 Cysteine-rich angiogenic inducer (CYP-61)
CCN2 Connective tissue growth factor (CTGF)
CCN3 Nephroblastoma overexpressed (Nov)
CCN4 Wnt-induced secreted protein-1 (WISP-1)
CCN5 WISP-2 connective tissue growth factor-like protein (CTGF-L)
CCN6 WISP-3
Periostin
Galectins
Plasminogen activator inhibitor type 1 (PAI-1)
Fibulin-5
Small leucine-rich proteoglycans (Biglycan, Decorin, Lumican,
Fibromodulin)

bone and teeth, which are subjected to strong mechanical stress.

\section{TENASCIN-C THE TENASCIN FAMILY}

Tenascins are a family of multimeric ECM glycoprotein characterized by an N-terminal globular domain and heptad repeats, which facilitate multimerization; one or more tenascin-type epidermal growth factor (EGF)-like repeats; a series of fibronectin (FN) type III domains, and a C-terminal fibrinogen-related domain. There are six names for the tenascin gene products: tenascin-C, $\mathrm{X}, \mathrm{R}, \mathrm{Y}$, W, and N (Tucker et al., 2006; Tucker and Chiquet-Ehrismann, 2009). TNC was the first tenascin found to be highly expressed in tendons and embryonic ECM (Chiquet-Ehrismann et al., 1986). It was discovered independently in several laboratories as glioma mesenchymal ECM antigen, myotendinous antigen, cytotactin, and J1 glycoprotein (reviewed in Tucker et al., 2006; ChiquetEhrismann and Tucker, 2011). Tenascin- $\mathrm{R}$ is the second member and is predominantly expressed in the central and peripheral nervous systems (Rathjen et al., 1991). Tenascin-X is a mammalian tenascin primarily expressed in loose connective tissue such as the dermis, epimysium, and blood vessels (Matsumoto et al., 1992; Bristow et al., 1993) Mutations in tenascin-X can lead to a type of Ehlers-Danlos Syndrome (reviewed in Bristow et al., 2005) Tenascin-Y is an avian tenascin similar to mammalian tenascin-X (Hagios et al., 1996). Tenascin-W (Weber et al., 1998) is found primarily in pre-osteogenic areas, the kidney, smooth muscle, and most prominently also in cancer stroma. Tenascin-N is most recently discovered tenascin and is similar to tenascin-W (Neidhardt et al., 2003).

\section{BIOLOGICAL ROLE OF TENASCIN-C}

TNC is the best characterized member of the family (Orend and Chiquet-Ehrismann, 2006; Midwood and Orend, 2009; ChiquetEhrismann and Tucker, 2011; Midwood et al., 2011; Udalova et al., 2011; Brellier and Chiquet-Ehrismann, 2012; ChiquetEhrismann et al., 2014) and is a typical matricellular protein. It is a huge molecule of approximately $220-400 \mathrm{kDa}$ as an intact monomer and is assembled as a hexamer. TNC is found in many developing organs of embryos, down-regulated after birth to a few tissues bearing high tensile stress and locations of high cell turnover, but highly up-regulated during injury, inflammation, regeneration, and cancer (Chiquet-Ehrismann et al., 2014). A number of in vitro studies suggest that TNC has a wide range of effects on cell adhesion, motility, differentiation, growth control, and ECM organization via multiple cell surface receptors including integrins $\alpha 9 \beta 1, \alpha v \beta 3$, and $\alpha v \beta 6$, Toll-like receptor 4 (TLR4) and syndecan-4 (Orend and Chiquet-Ehrismann, 2006; Midwood and Orend, 2009). As in the case of target disruption of several other matricellular protein genes, TNC knockout mice develop normally (Saga et al., 1992; Forsberg et al., 1996). Recent detailed investigations of various disease models using TNC KO have suggested that TNC may promote tissue healing but enhances inflammation and fibrosis (Midwood et al., 2011; Udalova et al., 2011; Brellier and ChiquetEhrismann, 2012; Imanaka-Yoshida, 2012; Chiquet-Ehrismann et al., 2014). 
During embryogenesis and tissue remodeling, TNC is expressed transiently at specific sites, suggesting that the expression of TNC is tightly regulated dependent on the cell type and tissue microenvironment (Tucker and Chiquet-Ehrismann, 2009). Many different growth factors, such as TGF $\beta$, FGF, PDGF, and proinflammatory cytokines, are able to induce TNC expression (for a review, see Orend and Chiquet-Ehrismann, 2006; Tucker and Chiquet-Ehrismann, 2009).

A variety of signaling pathways and transcription factors are known to stimulate TNC transcription (reviewed in ChiquetEhrismann and Tucker, 2011). These include TGF/Smad 3/4 (Jinnin et al., 2004), TLR4/NFkB (Goh et al., 2010), c-Jun/NFkB (Mettouchi et al., 1997), Notch (Sivasankaran et al., 2009), Sox4 (Scharer et al., 2009), PDGF/Ets (Jinnin et al., 2006), and MEF2c with scleraxis (della Gaspera et al., 2009). Conversely, TNC can trigger a variety of signaling pathways via multiple cell surface receptors. Interestingly, it affects some of the same signaling pathways that initially trigger the expression leading to negative or positive feedback loops (Chiquet-Ehrismann and Tucker, 2011). For example, PDGF can induce TNC expression via the phosphoinositide 3-kinase/Akt pathway (Jinnin et al., 2006) and MAPK pathways (Chiquet et al., 2004) and, in turn, TNC enhances PDGF signaling by cross-talk between PDGFR- $\beta$ and integrin $\alpha v \beta 3$ with activation of focal adhesion kinase and Src tyrosine kinase (Ishigaki et al., 2011). In contrast, a negative feedback loops is created in the case of small GTPase RhoA as discussed in the next section.

\section{INDUCTION OF TENASCIN-C BY MECHANO-STRESS}

Mechanical stress is also a strong inducer of TNC. Just as one of its original names, "myotendinous antigen," suggests, TNC is highly expressed at the myotendinous and osteotendinous junctions (Jarvinen et al., 1999, 2000, 2003) at sites subjected to mechanical stress. High expression of TNC is often observed at the branching point of arteries (Mackie et al., 1992), although the expression level of TNC is generally low in adult blood vessels. Based on this distribution of the molecule, the close association of mechanical stress and TNC has been proposed. Supporting this possibility, load-induced bone remodeling or muscle overload up-regulates the expression of TNC (Webb et al., 1997; Fluck et al., 2000; Mikic et al., 2000; Mackey et al., 2011), while immobilizing tendons down-regulates the expression. In culture, various mechanical stresses including stretching (Chiquet et al., 2004), compression (Jagodzinski et al., 2008), and shear stress (Tan et al., 2013), up-regulate TNC synthesis by fibroblasts, chondrocytes, smooth muscle cells, and endothelial cells.

Several types of cell-surface proteins, including stretchsensitive ion channels, are known to sense mechanical forces and translate them into biochemical signals (Kung, 2005). Mechanical inputs can be also detected by mechanosensing apparatus of the focal adhesion complex and transduced to the cytoskeleton (Wang et al., 2009). Chiquet and coworkers have shown a mechanism by which a mechano-signal is transduced at the linkage between the ECM and cytoskeleton, which controls TNC transcription mediated by megakaryoblastic leukemia 1 (MAL or MKL1)/myocardin-related transcription factor A (MRTFA) (Chiquet et al., 2007, 2009; Asparuhova et al., 2009, 2011; Brosig et al., 2010). The cycle stretch of fibroblasts up-regulates TNC transcription, independent of de novo protein synthesis, paracrine factors such as TGF $\beta$, and mitogen-activated protein kinases (MAPKs), but depends on actomyosin contractility controlled by the RhoA/ROCK pathway (Sarasa-Renedo et al., 2006) (Figure 1). Mechanical stimuli activate the signaling pathway involving integrin $\beta 1$ (Chiquet et al., 2007) and integrin-linked kinase (ILK) (Maier et al., 2008), which induces actin assembly and stress fiber formation via mDia and ROCK (Ridley and Hall, 1992). MAL/MLK1/MRTFA is a coactivator of serum response factor (SRF) and is predominantly localized in the cytoplasm through an interaction with G-actin (Miralles et al., 2003; Guettler et al., 2008). Therefore, depletion of the cytoplasmic G-actin pool following Rho activation causes translocation of MAL into the nucleus, where it induces TNC transcription, partly dependent on SRF (Asparuhova et al., 2011).

RhoA-dependent mechanotransduction requires pericellular fibronectin (Lutz et al., 2010). TNC binds fibronectin at the binding site to syndecan- 4 , a coreceptor for integrin $\alpha 5 \beta 1$, and has a negative impact on focal adhesion formation and activation of RhoA (Midwood et al., 2006; Lange et al., 2008; Van ObberghenSchilling et al., 2011). Therefore, mechanically induced TNC may lead to negative feedback from the mechanotrasduction signal. Moreover, since TNC is an elastic molecule that can be stretched to several times its resting length in vitro (Oberhauser et al., 1998; Marin et al., 2003), it may contribute to tissue elasticity and protect against mechanical stress.

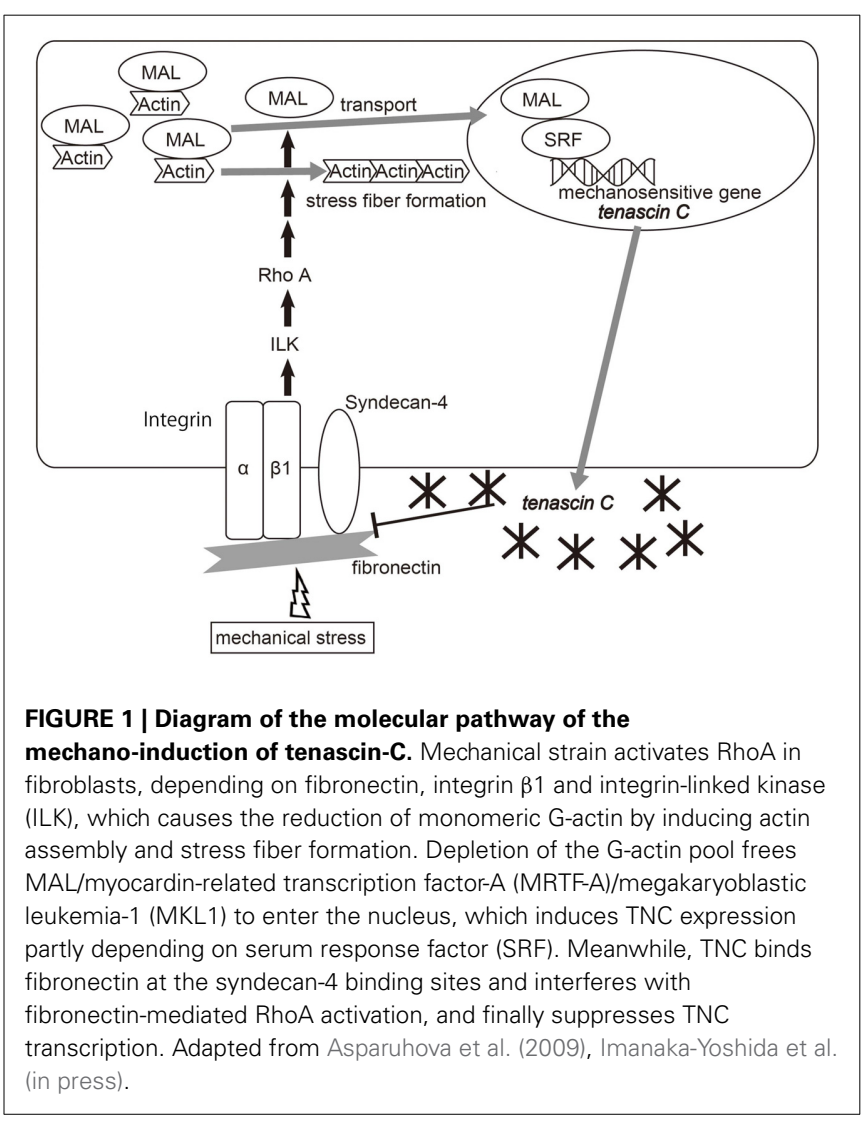




\section{MECHANOTRANSDUCTION AND TENASCIN-C IN CARDIOVASCULAR DEVELOPMENT}

During heart development, ECM not only provides structural support for embedded cells but plays an important biological role in the orchestration of cell behavior to form a complex structure with 4 chambers and 4 valves. Accumulated studies have shown diverse functions of various ECM molecules, including hyaluronan, proteoglycans, the collagen family, fibronectin, and periostin (reviewed in Lockhart et al., 2011).

\section{HEART DEVELOPMENT AND TENASCIN-C}

Specific roles of TNC in heart morphogenesis have long been anticipated based on its strictly regulated temporal expression at specific sites closely associated with cell migration and epithelialmesenchymal/mesenchymal-epithelial transition: (Wagenseil and Mecham, 2009) differentiation of precardiomyocytes, (Caulfield and Borg, 1979) cushion tissue formation, (Borg and Caulfield, 1981) valve formation, and (Hinton and Yutzey, 2011) coronary vessel formation (Imanaka-Yoshida et al., 2003).

During the development of mouse embryos, the initial expression of TNC is detected in mesodermal cells in the first heart field $(\mathrm{FHH})$, which undergo mesenchymal-epithelial transition and differentiate to cardiomyocytes and endocardial cells. Once the cells differentiate to cardiomyocytes, they rapidly stop expressing TN-C, while endocardial cells continue to express TNC. TNC expression is also detected at the recruitment of precardiac cells from the second heart field (SHF) (Imanaka-Yoshida et al., 2003). Interestingly, cardiomyocytes from the SHF in the outflow tract maintain the expression of TN-C during looping and shortening.

\section{Endocardial cushion and tenascin-C}

The primitive heart consists of the inner endocardium and outer myocardium and cardiac jelly, composed predominantly of the proteoglycan glycosaminoglycan hyaluronan between the two layers. After cardiac looping, the cardiac jelly expands within the AV canal and outflow tract regions and endocardial cells undergo epithelial-mesenchymal transformation (EMT) and invade it, forming an endocardial cushion (Eisenberg and Markwald, 1995; Person et al., 2005), which is the initial step in valvulogenesis.

A number of reports have demonstrated the expression of TNC in cushion tissue closely associated with EMT of endocardial cells (Hurle et al., 1990; Crossin and Hoffman, 1991; Zhang et al., 1993; Hiltgen et al., 1996; Sugi and Markwald, 1996; Boyer et al., 1999). Indeed, TNC promotes EMT of cancer cells in vitro (Nagaharu et al., 2011; Katoh et al., 2013).

Furthermore, Garita et al. have recently reported interesting results suggesting that TNC may provide a structural communication or mechano-communication between the myocardium and endocardium during looping. Using four-dimensional optical coherence tomography (OCT), they found that the endocardium was consistently oriented between the midline of the ventral floor of the foregut and the outer curvature of the myocardial wall throughout the cardiac cycle and that TN-C co-localized with FN at the attachment areas at the outer curvature of the heart wall to the ventral floor of the foregut (Garita et al., 2011).

\section{Valve development and tenascin-C}

Later stages of valvulogenesis involve thinning, elongation, and remodeling of the ECM of the primordial valve into three layers: the fibrosa, spongiosa and either the ventricularis of semilunar (SL) valve or the atrialis of the atrioventricular (AV) valve (Lincoln et al., 2004, 2006a; Hinton et al., 2006) (Figure 2). The atrialis/ventricularis are along the flow side of the valves and are rich in elastin fibers. The fibrosa is situated on the ventricular aspect of AV valves and the arterial aspect of the SL valves and is composed of well-organized collagen fibrils. The spongiosa layer of the valve leaflets is rich in chondroitin sulfate proteoglycan, aggrecan, similar to cartilage. The AV valve has supporting structures termed chordae tendinae composed of TNC-rich elastic matrix, which is similar to that of tendons. SL valves lack chordae
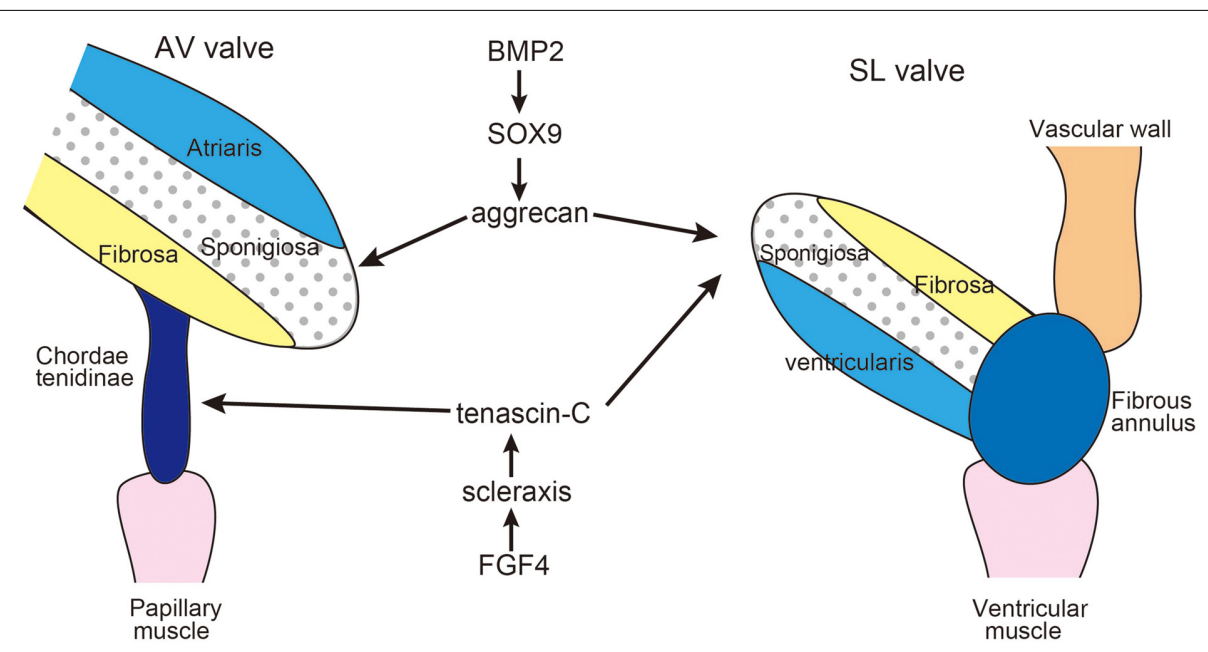

FIGURE 2 | Diagram of extracellular matrix compartmentalization of the mature $\mathbf{A V}$ and $\mathbf{S L}$ valves. During valve maturation, BMP2 signaling induces cartilage-associated genes Sox9 and aggrecan, while FGF4 signaling promotes expression of scleraxis and tenascin, which are characteristic of tendon cell lineages. SL valve precursor cells exhibit both cartilage and tendon-like characteristics. Adapted from Zhao et al. (2007), Hinton and Yutzey (2011). 
tendineae, but instead have comparable supporting tissue in the aortic and pulmonic roots and hinge regions (Zhao et al., 2007).

Remodeling of the heart valve primordia shares a regulatory pathway with developing cartilage/tendons (Lincoln et al., 2006b; Hinton and Yutzey, 2011). In the development of limb buds, diversification of cartilage and tendon cells from a common precursor is antagonistically regulated by BMP and FGF signaling pathways. BMP2 not only promotes chondrogenesis but also inhibits tendon development, while FGF4 promotes tendon differentiation (Edom-Vovard et al., 2002; Edom-Vovard and Duprez, 2004).

Similarly, BMP2 signaling activates valve progenitor cells to express Sox 9 transcription factor and the aggrecan gene as well as cartilage precursors in limb buds (Lincoln et al., 2006a; Zhao et al., 2007). In contrast, FGF4 signaling activates scleraxis and TNC expression in the valve-supporting apparatus as well as in developing tendons (Lincoln et al., 2006a; Zhao et al., 2007). Hemodynamics is often proposed to be one of the driving forces in valve development (Combs and Yutzey, 2009); however, there is no evidence indicating that mechano-stress might be involved in the induction of TNC during the development of the valves.

\section{VASCULAR DEVELOPMENT AND TENASCIN-C}

Another possibility is that TNC may play a role in blood vessel development. In coronary vessels, most vascular progenitors come from the proepicardial organ (PEO) between the primitive heart and the liver bud. Mesenchymal cells from the PEO migrate to the heart and form the epicardium. Epicardial cells undergo EMT, differentiate into endothelial cells and vascular smooth muscle cells (VSMCs), and form a primitive capillary network, which eventually connects to the aorta (see Nakajima and Imanaka-Yoshida, 2013, for review). During this process, TNC is transiently expressed in PEO before cell migration and at epicardial EMT. It is worthy of note that TNC is highly up-regulated and associated with thickening of the vascular wall after the premature vessels are linked with the aorta (Ando et al., 2011), possibly promoting the recruitment of vascular mural cells by facilitating PDGF-BB/PDGFR $\beta$ signaling (Ishigaki et al., 2011).

Similar up-regulation of TNC in the vascular wall associated with hemodynamic change is observed during the development of the aorta (Imanaka-Yoshida et al., in press). In E12-13 mouse embryos, weak expression of TNC is detected in the ascending, arch and descending aorta. After ED14-15, when the systemic circulatory system is established, TNC expression is evidently upregulated and becomes even stronger after birth. In normal adults, the expression of TNC in the aortic wall is generally reduced, although the infra-renal aorta continues to express TNC.

Despite its intriguing expression pattern during cardiovascular development, targeting deletion of the TNC gene causes a grossly normal phenotype (Saga et al., 1992; Forsberg et al., 1996). Our recent preliminary data suggested that over-expression of TNC in the heart may not cause a distinct phenotype, either (unpublished data). Compensatory mechanisms should be present in tissue morphogenesis of the embryo although it is not identified. However, increasing number of studies indicate that TNC is a "stress protein" whose importance becomes apparent when organ homeostasis is challenged by injury or destructive stress such as mechanical overload (Chiquet-Ehrismann et al., 2014), while it is masked during embryonic development.

\section{MECHANOTRANSDUCTION AND TENASCIN-C IN CARDIOVASCULAR DISEASE \\ MECHANOTRANSDUCTION IN HEART DISEASE}

In the heart, extracellular and intercellular mechanical loads are linked to the myofibrils in cardiomyocytes via various mechanosensing complexes (McCain and Parker, 2011). Cadherins links with myofibrils of neighboring cells at intercalated disks, while integrins attach Z-discs laterally to the connective tissue at costameres (Pardo et al., 1983a,b). Costameres are structures related to the focal adhesion complex and critical cytoskeletal elements involved in environmental mechanochemical signal transduction into cardiomyocytes (Samarel, 2005; Russell et al., 2010). They are also the sites where contractile forces generated within cardiomyocytes are transmitted to the surrounding interstitial collagen network (Danowski et al., 1992; Imanaka-Yoshida et al., 1996, 1999, 2004). Costameres may correspond to the myotendinous junction in the sense of transmitting contraction forces of muscle to connective tissue.

Although TNC is not detected in the normal myocardium, it transiently appears upon tissue injury and inflammation in various heart disease (Imanaka-Yoshida, 2012; Okamoto and Imanaka-Yoshida, 2012).

In an acute myocardial infarction model animal, TNC is exclusively localized at the border zone between the intact and infarcted lesion, the most active site of tissue remodeling (Imanaka-Yoshida et al., 2001; Nishioka et al., 2010). As a typical matricellular protein, TNC could loosen the strong costameric adhesion (Imanaka-Yoshida et al., 2001). This "de-adhesion" function may be useful to release surviving cardiomyocytes to reorganize their shape and arrangement; on the other hand, it should reduce the efficiency of the transduction of contraction force of cardiomyocytes. Furthermore, the border zone should be sites subjected to strong stress due to the difference in the physical property of the intact myocardium and necrotic tissue. By exploiting its elastic properties (Oberhauser et al., 1998; Marin et al., 2003), as discussed in the previous section TNC may protect surviving cardiomyocytes in the border zone as a shock absorber. However, there is no formal proof of this concept. In fact, deletion of TNC attenuates adverse ventricular remodeling and improves cardiac function after myocardial infarction in model mice (Nishioka et al., 2010). Therefore, the adaptive role of TNC in heart tissue remodeling has remained elusive.

\section{MECHANOTRANSDUCTION AND TENASCIN-C IN AORTIC DISEASE}

Recently, we found that TNC plays an adaptive role in maintaining the tissue strength of the aorta upon hemodynamic and humoral stress and protects aortic tissue from destructive events (Kimura et al., 2014). In this section we summarize our findings and propose the logic of a maintenance mechanism of tissue strength involving TNC. The aorta must maintain tensile strength to tolerate blood pressure, and must also maintain mechanical flexibility and elasticity to accommodate the stroke volume during the systolic phase and to keep the blood flowing during the diastolic phase. Because the blood pressure and stroke 
volume fluctuate during the cardiac cycle, circadian rhythm, and depending on physical and mental activities, aortic tissue must have a mechanism that locally optimizes these mechanical properties to meet the changes in hemodynamic demands. The failure of such a mechanism would lead to a mismatch between the mechanical properties and hemodynamic demands, causing central arterial hypertension in the case of excessive aortic stiffness (Agabiti-Rosei et al., 2007) or destructive aortic tissue remodeling including aortic aneurysm and aortic dissection (Cronenwett and Johnston, 2010). Because the mechanical properties of aortic tissue are determined mainly by the composition and architecture of ECM (Cronenwett and Johnston, 2010), the maintenance mechanism of aortic mechanical properties is expected to be tightly coupled with the ECM metabolism. TNC is one of the candidate molecules to maintain the strength of the tissue against mechanical stress.

\section{Acute aortic dissection}

Acute aortic dissection (AAD) is a medical emergency and the most common aortic disease that is life-threatening (Cronenwett and Johnston, 2010). Patients usually experience the sudden onset of chest or back pain that typically migrates along with the progression of the tearing of the aortic wall. Because patients experience no preceding symptoms, the exact sequence of the events during AAD onset is unknown. However, it is generally accepted that AAD starts with the tearing of the intimomedial layer of the aortic wall, followed by circumferential and longitudinal tearing of the aortic medial wall due to blood rushing into the pseudolumen that is formed between the inner and outer layers of the torn medial layer of the aortic wall. Several genetic disorders are known to predispose the suffering individuals to AAD, including Marfan syndrome, Loeys-Dietz syndrome, vascular Ehlers-Danlos syndrome, bicuspid aortic valve, Turner syndrome, and familial thoracic aortic aneurysm and dissection. However, these genetic disorders account for up to $10 \%$ of AAD cases (Cronenwett and Johnston, 2010) and little is known about the etiology of other cases. In addition, the molecular pathogenesis of AAD is largely unknown, partly because animal models that recapitulate the pathological features of human AAD are not available, except for those that are models of genetic disorders.

\section{Aortic stress model in mice}

During the investigation into the pathophysiological role of TNC in the aorta under mechanical and humoral stress, we discovered that deletion of TNC renders mice susceptible to AAD (Kimura et al., 2014). We created a mouse model of aortic stress by inducing aortic stiffness and hypertension (Figure 3), known risk factors for AAD (Jondeau et al., 1999). Aortic stiffness was induced by periaortic treatment of the infrarenal aorta by $0.5 \mathrm{M} \mathrm{CaCl}_{2}$, which causes disruption of the elastic lamellae and strong periaortic fibrosis (Ca treatment). Hypertension was induced by continuous infusion of angiotensin II $(1 \mu \mathrm{g} / \mathrm{kg} / \mathrm{min}$; AngII treatment), which is known to induce constriction and a proinflammatory response in the vasculature.

The increase in stress in this model was verified by the direct measurement of aortic pressure waves with catheterization. $\mathrm{Ca}$ treatment caused an increase in the maximal $\mathrm{dP} / \mathrm{dt}$ of the distal aorta, while AngII infusion increased that of the proximal

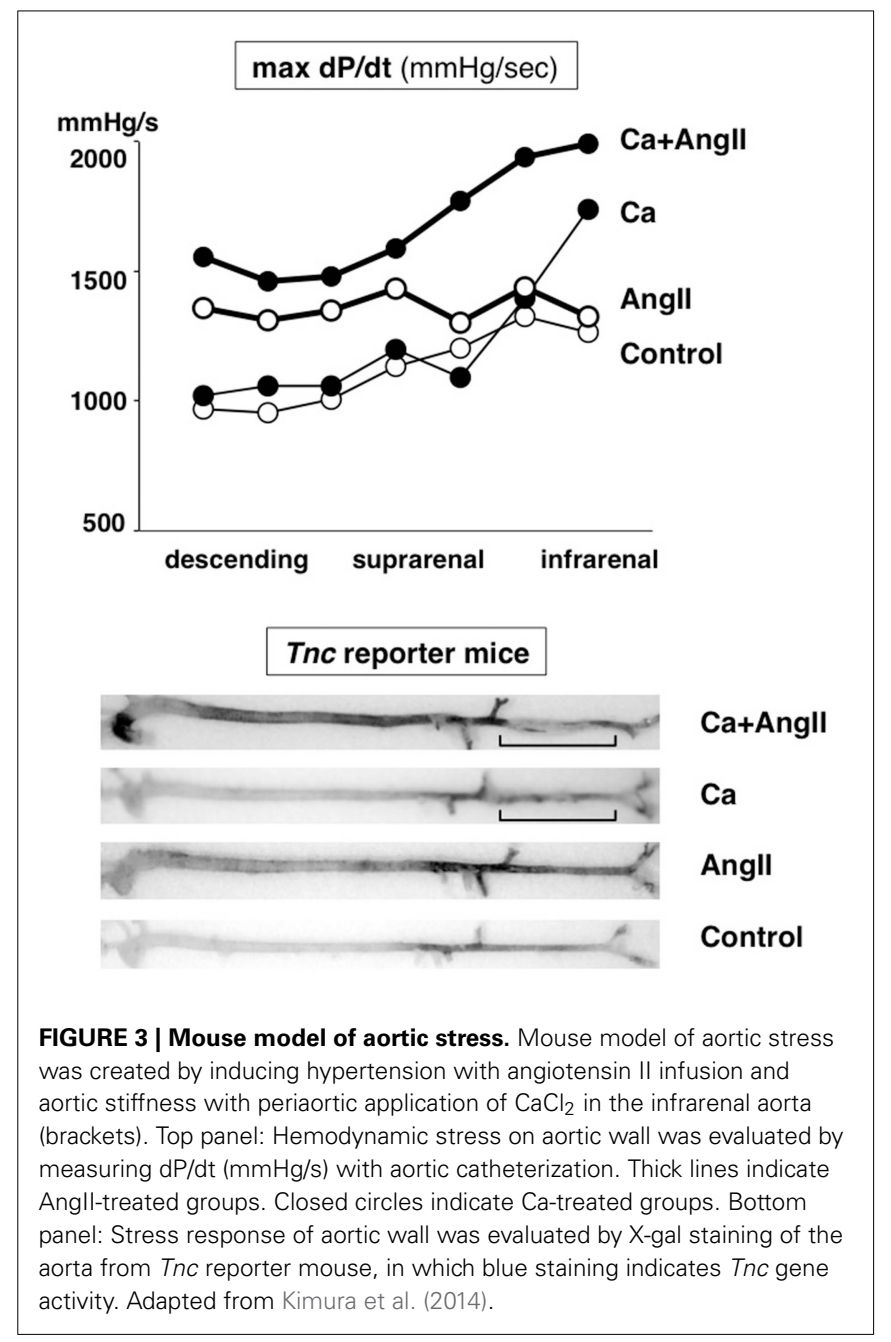

aorta. The combination of $\mathrm{Ca}$ and AngII treatments (Ca+AngII) increased the $\mathrm{dP} / \mathrm{dt}$ throughout the aorta. The expression of TNC, as monitored in TNC reporter mice into which the lac $Z$ gene was introduced into one of the Tnc loci, was observed exclusively in medial smooth muscle cells and faithfully followed the increase in $\mathrm{dP} / \mathrm{dt}$.

\section{Acute aortic dissection in mice}

To understand the function of TNC in this aortic stress model, we applied $\mathrm{Ca}+$ AngII treatment to TNC knockout mice (TNC$\mathrm{KO})$. Remarkably, only TNC-KO mice developed AAD in the suprarenal aorta (Figure 4), while WT mice showed only aortic wall thickening in the same region of the aorta. Treatment with $\mathrm{Ca}$ alone or AngII alone did not induce AAD in either WT or TNC-KO mice. It should be noted that AAD developed in the suprarenal aorta, which is distant from the Ca-treated infrarenal aorta, and in almost all of the cases of AAD we observed a normal-looking segment of the aorta in between. This observation indicated that direct propagation of the inflammation from the Ca-treated infrarenal aorta cannot explain AAD development in the suprarenal aorta. The finding that $\mathrm{Ca}+\mathrm{AngII}$ treatment greatly enhanced hemodynamic stress led us to conclude that the 

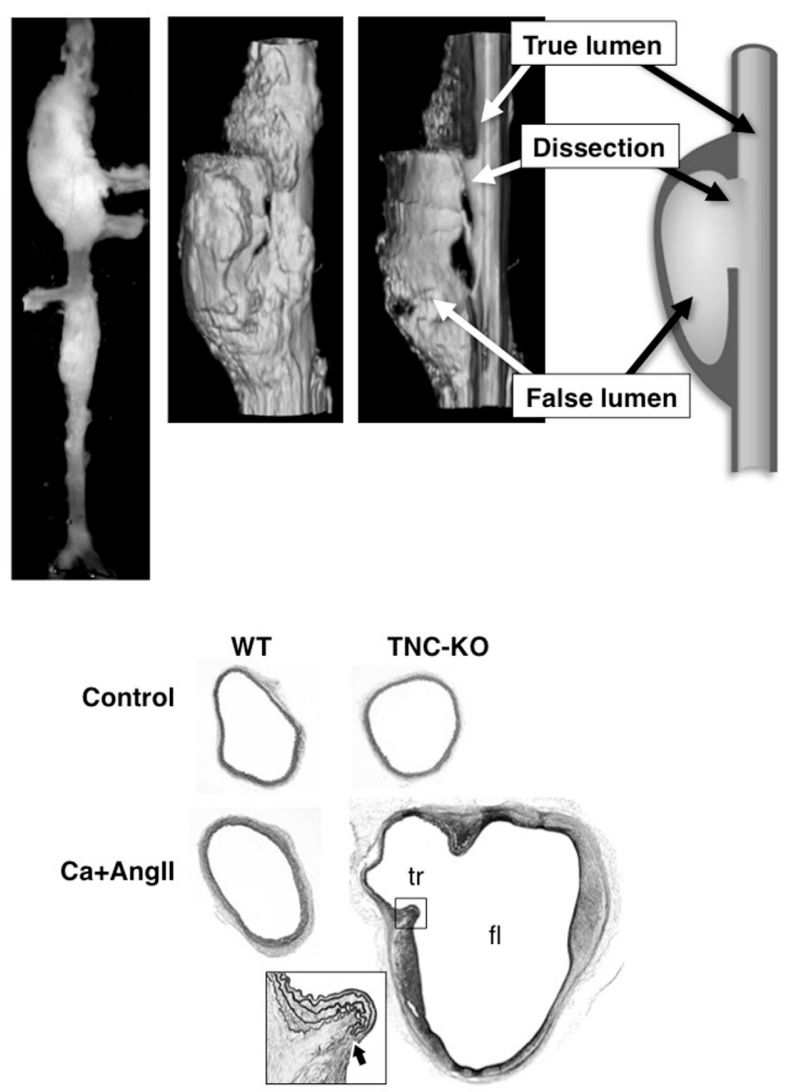

FIGURE 4 | AAD in TNC-KO mice. Morphology of mouse AAD in TNC-KO mice. Top panels: A macroscopic image, 3D-reconstitution of optical sections obtained by optical coherence tomography with a cut-out view, and a schematic of the cut-out view. Bottom panels: Elastica van Gieson staining of the suprarenal aorta. True (tr) and false ( $\mathrm{fl}$ ) lumens are indicated in TNC-KO with $\mathrm{Ca}+$ Angll treatment. The inset is the magnified view of the dissection site (thick arrow) as indicated by the rectangle. Adapted from Kimura et al. (2014).

augmented hemodynamic stress was at least partly responsible for AAD development in TNC-KO mice.

$\mathrm{AAD}$ in TNC-KO mice recapitulated the main features of the human aorta, including disruption of the intimomedial layers with otherwise preserved elastic lamellar architecture, intramural hematoma, and formation of a pseudolumen with a double-barrel appearance. One important feature of human AAD was missing; longitudinal dissection of the medial layer. This is probably because the medial layer of the human aortic wall consists of about a 100 layers of elastic lamellae, while that of the mouse aortic wall consists of only 4-7 layers. Therefore, disruption of only a few elastic lamellae would result in complete disruption of the intimomedial layers, leaving only adventitia.

Transcriptome analysis before AAD development revealed the impaired induction of ECM protein genes and exaggerated the induction of proinflammatory genes in the suprarenal aorta of TNC-KO compared to WT (Kimura et al., 2014). Measurement of the tensile strength of the suprarenal aorta in WT showed a transient reduction 1 week after $\mathrm{Ca}+$ AngII treatment, which recovered 6 weeks after $\mathrm{Ca}+\mathrm{AngII}$, probably due to the induction of ECM proteins. In contrast, the strength of the suprarenal aorta of TNC-KO mice showed more marked weakening 1 week after $\mathrm{Ca}+$ AngII treatment, likely reflecting the impaired induction of ECM proteins. Thus, deletion of the Tnc gene and the resultant impairment of ECM gene induction showed a significant impact on the adaptive response in reinforcing tissue strength against the increase in hemodynamic stress.

The exaggerated induction of proinflammatory genes in the TNC-KO aorta may also have a significant impact on the homeostasis of aortic tissue. Indeed, imaging cytometric analysis of the TNC-KO aorta showed much more infiltration of CD45positive inflammatory cells that showed stronger activation of NFאB and STAT3 compared to the WT aorta before AAD development, probably reflecting the proinflammatory environment in the TNC-KO aorta. Interestingly, activation of SMAD2, a downstream molecule of TGF $\beta$ signaling, was reduced in VSMCs in the TNC-KO aorta, concomitant with the reduction in the expression of smooth muscle $\alpha$-actin, indicative of compromised VSMC differentiation. Impaired TGF $\beta$ signaling may explain the impairment of both the differentiation of VSMCs and induction of ECM genes, because TGF $\beta$ is a strong inducer of VSMC differentiation (Kumar and Owens, 2003) and a master regulator of ECM genes (Bobik, 2006). Consistently, TGF $\beta$ is reported to protect the aorta from rupture by angiotensin II infusion in ApoE-deficient mice (Wang et al., 2010), possibly by stabilizing the inflamed aortic tissue (Dai et al., 2005), in contrast to its pathogenic role in Marfan syndrome (Dietz, 2010). Modulation of the cytokine environment may explain the marked reduction in the tensile strength of the aorta and $\mathrm{AAD}$ development upon aortic stress by $\mathrm{Ca}+$ AngII treatment in TNC-KO mice, although exactly how TNC modulates the cytokine environment remains to be elucidated.

\section{Role of tenascin-C in the protection of aortic tissue}

From the viewpoint of aortic homeostasis and AAD pathogenesis, TNC can be regarded as a stress-activated molecular damper (Figure 5); it is inactive under normal conditions, but once the tissue experiences high mechanical stress it is activated and works to reinforce tissue strength by inducing ECM proteins and at the same time by ameliorating the excessive proinflammatory response. These findings may be clinically relevant, because elevation of tissue and serum TNC levels has been reported in both Stanford type A and type B human AAD (Nozato et al., 2013; Trescher et al., 2013). It is also noteworthy that in TNC-KO mice, aortic wall stiffness was increased only in the infrarenal abdominal aorta where TNC was expressed at a low level (our unpublished data). This suggests that TNC may also participate in the maintenance of the flexibility of aortic walls in certain situations.

\section{ADAPTIVE ROLE OF TENASCIN-C IN THE MECHANICAL STRESS RESPONSE}

As observed in the aortic stress model discussed above, adaptive or destructive tissue remodeling upon hemodynamic and humoral stress could be associated with the inflammatory response. Indeed, mechanical forces influence the production of 


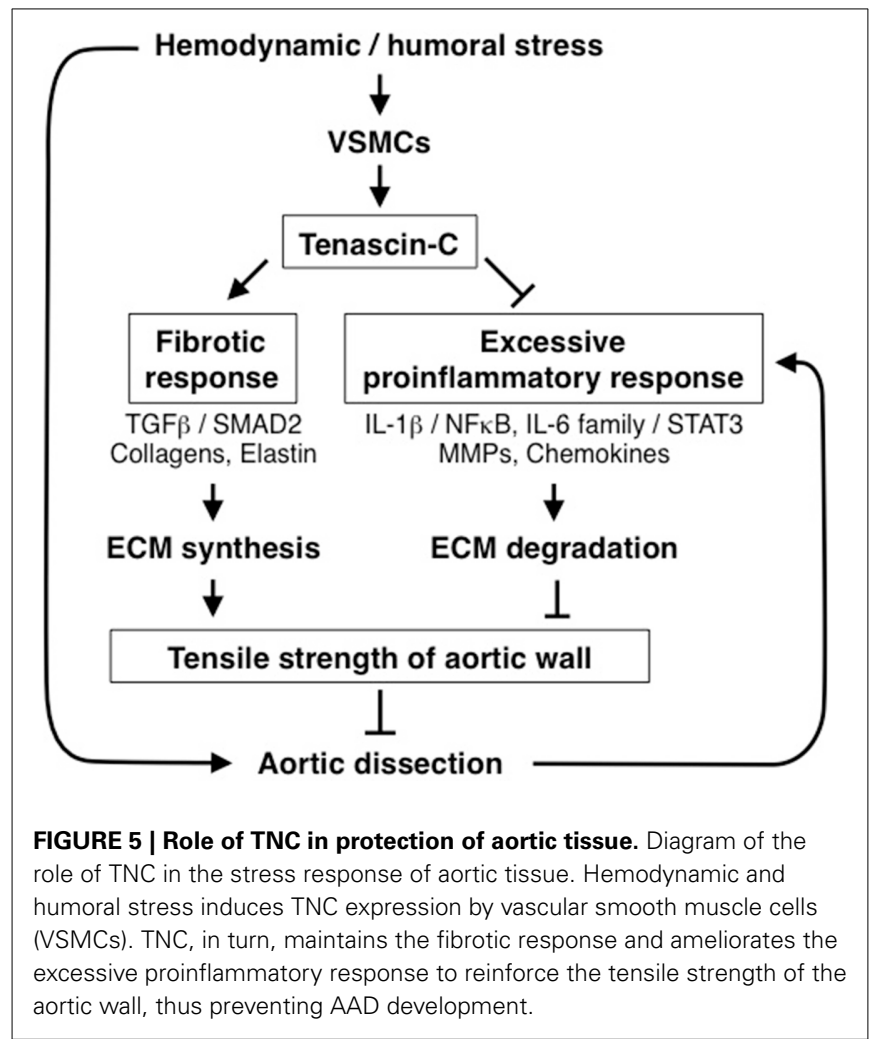

inflammatory mediators (Wang and Thampatty, 2008; Yang et al., 2008). Alternatively, strong mechanical stress may cause minimal injury, which would evoke inflammation and secondary matrix synthesis as a repairing response.

Generally, TNC expression is closely associated with tissue injury and inflammation in various pathological states, which makes TNC a hallmark of inflammation for clinical diagnosis (Imanaka-Yoshida, 2012; Okamoto and Imanaka-Yoshida, 2012). In fact, inflammatory cytokines induce TNC. A growing body of evidence suggests that TNC activates TLR4 signaling, leading to greater cytokine secretion and more TNC synthesis, forming a positive feedback loop to augment inflammation (Midwood et al., 2009; Goh et al., 2010). The exaggerated induction of proinflammatory genes in the stressed aorta of TNC-KO seems to be inconsistent with the current consensus. It is well-known that TNC has diverse functions in a context-dependent manner and they are sometimes conflicting. Since TNC can bind various cellsurface receptors, different signals from one molecule may be transduced via different receptors depending on the cell type.

Obviously, TNC is not the only ECM molecule involved in the response to mechanical stress. Mechanical stimuli can generally up-regulate the gene expression, synthesis and organization of various ECM molecules. In particular, several matricellular proteins, including CCN1 (Hanna et al., 2009), CCN2 (CTGF) (Schild and Trueb, 2004; Chaqour et al., 2006; Honjo et al., 2012), osteopontin (Endlich et al., 2002), SPARC (Durvasula and Shankland, 2005), and periostin (Yamashita et al., 2013) are induced by mechanical stimuli depending on actin cytoskeleton via common or different pathways. These matricellular proteins show a similar expression pattern to TNC and could modulate the signal transduction and activity of the cells. Furthermore, some are co-localized with TNC and can cooperate or counterbalance each other. For example, TNC and osteopontin are strongly induced in spastic cerebral arteries in a subarachnoid hemorrhage model and TNC induces vasospasm, which is reversed by osteopontin (Suzuki et al., 2013). Periostin directly binds TNC, promoting the organization of a fibrous matrix (Kii et al., 2010). Complex networks of multiple ECM molecules, including matricellular protein, may regulate the adaptive and plasticity responses of the tissue to mechanical overload.

Despite this potential compensatory mechanism, deletion of TNC causes AAD under strong mechanical and humoral stress, which suggests that TNC could play a critical role in protecting vascular tissue from destructive stress responses.

\section{CONCLUSION}

TNC may be one of the extracellular key modulators controlling the cellular response to mechanical load during development as well as during adaptation or pathological tissue remodeling.

\section{ACKNOWLEDGMENTS}

The authors thank T. Akatuska for drawing the illustration for this manuscript. This work was supported in part by a Research Grant for Intractable Diseases from the Ministry of Health, Labor and Welfare of Japan (Kyoko Imanaka-Yoshida), Grantin-Aid for Scientific Research from MEXT Japan, a Grant from Vehicle Racing Commemorative Foundation and a Grant from the Uehara Memorial Foundation (Hiroki Aoki).

\section{REFERENCES}

Agabiti-Rosei, E., Mancia, G., O’Rourke, M. F., Roman, M. J., Safar, M. E., Smulyan, H., et al. (2007). Central blood pressure measurements and antihypertensive therapy: a consensus document. Hypertension 50, 154-160. doi: 10.1161/HYPERTENSIONAHA.107.090068

Ando, K., Takahashi, M., Yamagishi, T., Miyagawa-Tomita, S., Imanaka-Yoshida, K., Yoshida, T., et al. (2011). Tenascin C may regulate the recruitment of smooth muscle cells during coronary artery development. Differentiation 81, 299-306. doi: 10.1016/j.diff.2011.03.002

Asparuhova, M. B., Ferralli, J., Chiquet, M., and Chiquet-Ehrismann, R. (2011). The transcriptional regulator megakaryoblastic leukemia-1 mediates serum response factor-independent activation of tenascin- $\mathrm{C}$ transcription by mechanical stress. FASEB J. 25, 3477-3488. doi: 10.1096/fj.11187310

Asparuhova, M. B., Gelman, L., and Chiquet, M. (2009). Role of the actin cytoskeleton in tuning cellular responses to external mechanical stress. Scand. J. Med. Sci. Sports 19, 490-499. doi: 10.1111/j.1600-0838.2009.00928.x

Bobik, A. (2006). Transforming growth factor-betas and vascular disorders. Arterioscler. Thromb. Vasc. Biol. 26, 1712-1720. doi: 10.1161/01.ATV.0000225287.20034.2c

Borg, T. K., and Baudino, T. A. (2011). Dynamic interactions between the cellular components of the heart and the extracellular matrix. Pflugers Arch. 462, 69-74. doi: 10.1007/s00424-011-0940-7

Borg, T. K., and Caulfield, J. B. (1981). The collagen matrix of the heart. Fed. Proc. 40, 2037-2041.

Bornstein, P. (2009). Matricellular proteins: an overview. J. Cell Commun. Signal. 3, 163-165. doi: 10.1007/s12079-009-0069-z

Bornstein, P., and Sage, E. H. (2002). Matricellular proteins: extracellular modulators of cell function. Curr. Opin. Cell Biol. 14, 608-616. doi: 10.1016/S09550674(02)00361-7

Bowers, S. L., Banerjee, I., and Baudino, T. A. (2010). The extracellular matrix: at the center of it all. J. Mol. Cell. Cardiol. 48, 474-482. doi: 10.1016/j.yjmcc.2009.08.024 
Boyer, A. S., Erickson, C. P., and Runyan, R. B. (1999). Epithelial-mesenchymal transformation in the embryonic heart is mediated through distinct pertussis toxin-sensitive and TGFbeta signal transduction mechanisms. Dev. Dyn. 214, 81-91. doi: 10.1002/(sici)1097-0177(199901)214:1<81::aid-dvdy $8>3.0 . \operatorname{co} ; 2-3$

Brellier, F., and Chiquet-Ehrismann, R. (2012). How do tenascins influence the birth and life of a malignant cell? J. Cell. Mol. Med. 16, 32-40. doi: 10.1111/j.1582-4934.2011.01360.x

Bristow, J., Carey, W., Egging, D., and Schalkwijk, J. (2005). Tenascin-X, collagen, elastin, and the Ehlers-Danlos syndrome. Am. J. Med. Genet. C Semin. Med. Genet. 139C, 24-30. doi: 10.1002/ajmg.c.30071

Bristow, J., Tee, M. K., Gitelman, S. E., Mellon, S. H., and Miller, W. L. (1993). Tenascin-X: a novel extracellular matrix protein encoded by the human XB gene overlapping P450c21B. J. Cell Biol. 122, 265-278. doi: 10.1083/jcb. 122.1.265

Brosig, M., Ferralli, J., Gelman, L., Chiquet, M., and Chiquet-Ehrismann, R. (2010). Interfering with the connection between the nucleus and the cytoskeleton affects nuclear rotation, mechanotransduction and myogenesis. Int. J. Biochem. Cell Biol. 42, 1717-1728. doi: 10.1016/j.biocel.2010.07.001

Caulfield, J. B., and Borg, T. K. (1979). The collagen network of the heart. Lab. Invest. 40, 364-372.

Chaqour, B., Yang, R., and Sha, Q. (2006). Mechanical stretch modulates the promoter activity of the profibrotic factor CCN2 through increased actin polymerization and NF-kappaB activation. J. Biol. Chem. 281, 20608-20622. doi: 10.1074/jbc.M600214200

Chiquet, M., Gelman, L., Lutz, R., and Maier, S. (2009). From mechanotransduction to extracellular matrix gene expression in fibroblasts. Biochim. Biophys. Acta 1793, 911-920. doi: 10.1016/j.bbamcr.2009.01.012

Chiquet, M., Sarasa-Renedo, A., and Tunc-Civelek, V. (2004). Induction of tenascin-C by cyclic tensile strain versus growth factors: distinct contributions by Rho/ROCK and MAPK signaling pathways. Biochim. Biophys. Acta 1693, 193-204. doi: 10.1016/j.bbamcr.2004.08.001

Chiquet, M., Tunc-Civelek, V., and Sarasa-Renedo, A. (2007). Gene regulation by mechanotransduction in fibroblasts. Appl. Physiol. Nutr. Metab. 32, 967-973. doi: 10.1139/H07-053

Chiquet-Ehrismann, R., Mackie, E. J., Pearson, C. A., and Sakakura, T. (1986). Tenascin: an extracellular matrix protein involved in tissue interactions during fetal development and oncogenesis. Cell 47, 131-139. doi: 10.1016/00928674(86)90374-0

Chiquet-Ehrismann, R., Orend, G., Chiquet, M., Tucker, R. P., and Midwood, K. S. (2014). Tenascins in stem cell niches. Matrix Biol. doi: 10.1016/j.matbio.2014.01.007. [Epub ahead of print].

Chiquet-Ehrismann, R., and Tucker, R. P. (2011). Tenascins and the importance of adhesion modulation. Cold Spring Harb. Perspect. Biol. 3:a004960. doi: 10.1101/ cshperspect.a004960

Combs, M. D., and Yutzey, K. E. (2009). Heart valve development: regulatory networks in development and disease. Circ. Res. 105, 408-421. doi: 10.1161/CIRCRESAHA.109.201566

Conway, S. J., and Molkentin, J. D. (2008). Periostin as a heterofunctional regulator of cardiac development and disease. Curr. Genomics 9, 548-555. doi: $10.2174 / 138920208786847917$

Cronenwett, J. L., and Johnston, W. (2010). Rutherford's Vascular Surgery, 7th Edn. Philadelphia: Saunders.

Crossin, K. L., and Hoffman, S. (1991). Expression of adhesion molecules during the formation and differentiation of the avian endocardial cushion tissue. Dev. Biol. 145, 277-286. doi: 10.1016/0012-1606(91)90126-N

Dai, J., Losy, F., Guinault, A. M., Pages, C., Anegon, I., Desgranges, P., et al. (2005). Overexpression of transforming growth factor-betal stabilizes already-formed aortic aneurysms: a first approach to induction of functional healing by endovascular gene therapy. Circulation 112, 1008-1015. doi: 10.1161/CIRCULATIONAHA.104.523357

Danowski, B. A., Imanaka-Yoshida, K., Sanger, J. M., and Sanger, J. W. (1992). Costameres are sites of force transmission to the substratum in adult rat cardiomyocytes. J. Cell Biol. 118, 1411-1420. doi: 10.1083/jcb.118. 6.1411

della Gaspera, B., Armand, A. S., Sequeira, I., Lecolle, S., Gallien, C. L., Charbonnier, F., et al. (2009). The Xenopus MEF2 gene family: evidence of a role for XMEF2C in larval tendon development. Dev. Biol. 328, 392-402. doi: 10.1016/j.ydbio.2009.01.039
Dietz, H. C. (2010). TGF-beta in the pathogenesis and prevention of disease: a matter of aneurysmic proportions. J. Clin. Invest. 120, 403-407. doi: 10.1172/JCI42014

Durvasula, R. V., and Shankland, S. J. (2005). Mechanical strain increases SPARC levels in podocytes: implications for glomerulosclerosis. Am. J. Physiol. Renal Physiol. 289, F577-F584. doi: 10.1152/ajprenal.00393.2004

Edom-Vovard, F., and Duprez, D. (2004). Signals regulating tendon formation during chick embryonic development. Dev. Dyn. 229, 449-457. doi: 10.1002/dvdy. 10481

Edom-Vovard, F., Schuler, B., Bonnin, M. A., Teillet, M. A., and Duprez, D. (2002). Fgf4 positively regulates scleraxis and tenascin expression in chick limb tendons. Dev. Biol. 247, 351-366. doi: 10.1006/dbio.2002.0707

Eisenberg, L. M., and Markwald, R. R. (1995). Molecular regulation of atrioventricular valvuloseptal morphogenesis. Circ. Res. 77, 1-6. doi: 10.1161/01. RES.77.1.1

Endlich, N., Sunohara, M., Nietfeld, W., Wolski, E. W., Schiwek, D., Kranzlin, B., et al. (2002). Analysis of differential gene expression in stretched podocytes: osteopontin enhances adaptation of podocytes to mechanical stress. FASEB J. 16, 1850-1852. doi: 10.1096/fj.02-0125fje

Fluck, M., Tunc-Civelek, V., and Chiquet, M. (2000). Rapid and reciprocal regulation of tenascin- $\mathrm{C}$ and tenascin-Y expression by loading of skeletal muscle. J. Cell Sci. 113, 3583-3591.

Forsberg, E., Hirsch, E., Frohlich, L., Meyer, M., Ekblom, P., Aszodi, A., et al. (1996). Skin wounds and severed nerves heal normally in mice lacking tenascin-C. Proc. Natl. Acad. Sci. U.S.A. 93, 6594-6599. doi: 10.1073/pnas.93. 13.6594

Garita, B., Jenkins, M. W., Han, M., Zhou, C., Vanauker, M., Rollins, A. M., et al. (2011). Blood flow dynamics of one cardiac cycle and relationship to mechanotransduction and trabeculation during heart looping. Am. J. Physiol. Heart Circ. Physiol. 300, H879-H891. doi: 10.1152/ajpheart.00433.2010

Ghatak, S., Misra, S., Norris, R. A., Moreno-Rodriguez, R. A., Hoffman, S., Levine, R. A., et al. (2014). Periostin induces intracellular cross-talk between kinases and hyaluronan in atrioventricular valvulogenesis. J. Biol. Chem. 289, 8545-8561. doi: 10.1074/jbc.M113.539882

Goh, F. G., Piccinini, A. M., Krausgruber, T., Udalova, I. A., and Midwood, K. S. (2010). Transcriptional regulation of the endogenous danger signal tenascinC: a novel autocrine loop in inflammation. J. Immunol. 184, 2655-2662. doi: 10.4049/jimmunol.0903359

Guettler, S., Vartiainen, M. K., Miralles, F., Larijani, B., and Treisman, R. (2008). RPEL motifs link the serum response factor cofactor MAL but not myocardin to Rho signaling via actin binding. Mol. Cell Biol. 28, 732-742. doi: 10.1128/MCB.01623-07

Hagios, C., Koch, M., Spring, J., Chiquet, M., and Chiquet-Ehrismann, R. (1996). Tenascin-Y: a protein of novel domain structure is secreted by differentiated fibroblasts of muscle connective tissue. J. Cell Biol. 134, 1499-1512. doi: 10.1083/jcb.134.6.1499

Hanna, M., Liu, H., Amir, J., Sun, Y., Morris, S. W., Siddiqui, M. A., et al. (2009). Mechanical regulation of the proangiogenic factor CCN1/CYR61 gene requires the combined activities of MRTF-A and CREB-binding protein histone acetyltransferase. J. Biol. Chem. 284, 23125-23136. doi: 10.1074/jbc.M109. 019059

Hiltgen, G. G., Markwald, R. R., and Litke, L. L. (1996). Morphogenetic alterations during endocardial cushion development in the trisomy 16 (Down syndrome) mouse. Pediatr. Cardiol. 17, 21-30. doi: 10.1007/BF02505807

Hinton, R. B. Jr., Lincoln, J., Deutsch, G. H., Osinska, H., Manning, P. B., Benson, D. W., et al. (2006). Extracellular matrix remodeling and organization in developing and diseased aortic valves. Circ. Res. 98, 1431-1438. doi: 10.1161/01.RES.0000224114.65109.4e

Hinton, R. B., and Yutzey, K. E. (2011). Heart valve structure and function in development and disease. Annu. Rev. Physiol. 73, 29-46. doi: 10.1146/annurevphysiol-012110-142145

Honjo, T., Kubota, S., Kamioka, H., Sugawara, Y., Ishihara, Y., Yamashiro, T., et al. (2012). Promotion of Ccn2 expression and osteoblastic differentiation by actin polymerization, which is induced by laminar fluid flow stress. J. Cell Commun. Signal. 6, 225-232. doi: 10.1007/s12079-012-0177-z

Hurle, J. M., Garcia-Martinez, V., and Ros, M. A. (1990). Immunofluorescent localization of tenascin during the morphogenesis of the outflow tract of the chick embryo heart. Anat. Embryol. (Berl.) 181, 149-155. doi: 10.1007/BF001 98954 
Imanaka-Yoshida, K. (2012). Tenascin-C in cardiovascular tissue remodeling. Circ J. 76, 2513-2520. doi: 10.1253/circj.CJ-12-1033

Imanaka-Yoshida, K., Danowski, B. A., Sanger, J. M., and Sanger, J. W. (1996). Living adult rat cardiomyocytes in culture: evidence for dissociation of costameric distribution of vinculin from costameric distributions of attachments. Cell Motil. Cytoskeleton 33, 263-275. doi: 10.1002/(sici)10970169(1996)33:4<263::aid-cm3>3.0.co;2-a

Imanaka-Yoshida, K., Enomoto-Iwamoto, M., Yoshida, T., and Sakakura, T. (1999). Vinculin, Talin, Integrin alpha6betal and laminin can serve as components of attachment complex mediating contraction force transmission from cardiomyocytes to extracellular matrix. Cell Motil. Cytoskeleton 42, 1-11. doi: 10.1002/(sici) 1097-0169(1999)42:1<1::aid-cm1>3.0.co;2-0

Imanaka-Yoshida, K., Hiroe, M., and Yoshida, T. (2004). Interaction between cell and extracellular matrix in heart disease: multiple roles of tenascin-C in tissue remodeling. Histol. Histopathol. 19, 517-525.

Imanaka-Yoshida, K., Hiroe, M., Nishikawa, T., Ishiyama, S., Shimojo, T., Ohta, Y., et al. (2001). Tenascin-C modulates adhesion of cardiomyocytes to extracellular matrix during tissue remodeling after myocardial infarction. Lab. Invest. 81, 1015-1024. doi: 10.1038/labinvest.3780313

Imanaka-Yoshida, K., Matsumoto, K., Hara, M., Sakakura, T., and Yoshida, T. (2003). The dynamic expression of tenascin- $\mathrm{C}$ and tenascin-X during early heart development in the mouse. Differentiation 71, 291-298. doi: 10.1046/j.14320436.2003.7104506.x

Imanaka-Yoshida, K., Miyagawa-Tomita, S., and Yoshida, T. (in press). Tenascin-C in development and disease of blood vessels. Anat. Rec.

Inai, K., Norris, R. A., Hoffman, S., Markwald, R. R., and Sugi, Y. (2008). BMP-2 induces cell migration and periostin expression during atrioventricular valvulogenesis. Dev. Biol. 315, 383-396. doi: 10.1016/j.ydbio.2007. 12.028

Ishigaki, T., Imanaka-Yoshida, K., Shimojo, N., Matsushima, S., Taki, W., and Yoshida, T. (2011). Tenascin-C enhances crosstalk signaling of integrin alphavbeta3/PDGFR-beta complex by SRC recruitment promoting PDGFinduced proliferation and migration in smooth muscle cells. J. Cell. Physiol. 226, 2617-2624. doi: 10.1002/jcp.22614

Jagodzinski, M., Breitbart, A., Wehmeier, M., Hesse, E., Haasper, C., Krettek, C., et al. (2008). Influence of perfusion and cyclic compression on proliferation and differentiation of bone marrow stromal cells in 3dimensional culture. J. Biomech. 41, 1885-1891. doi: 10.1016/j.jbiomech.2008. 04.001

Jarvinen, T. A., Jozsa, L., Kannus, P., Jarvinen, T. L., Hurme, T., Kvist, M., et al. (2003). Mechanical loading regulates the expression of tenascin-C in the myotendinous junction and tendon but does not induce de novo synthesis in the skeletal muscle. J. Cell Sci. 116, 857-866. doi: 10.1242/ jcs. 00303

Jarvinen, T. A., Jozsa, L., Kannus, P., Jarvinen, T. L., Kvist, M., Hurme, T., et al. (1999). Mechanical loading regulates tenascin-C expression in the osteotendinous junction. J. Cell Sci. 112, 3157-3166.

Jarvinen, T. A., Kannus, P., Jarvinen, T. L., Jozsa, L., Kalimo, H., and Jarvinen, M. (2000). Tenascin-C in the pathobiology and healing process of musculoskeletal tissue injury. Scand. J. Med. Sci. Sports 10, 376-382. doi: 10.1034/j.16000838.2000.010006376.x

Jinnin, M., Ihn, H., Asano, Y., Yamane, K., Trojanowska, M., and Tamaki, K. (2004). Tenascin-C upregulation by transforming growth factor-beta in human dermal fibroblasts involves Smad3, Sp1, and Ets1. Oncogene 23, 1656-1667. doi: 10.1038/sj.onc. 1207064

Jinnin, M., Ihn, H., Asano, Y., Yamane, K., Trojanowska, M., and Tamaki, K. (2006). Platelet derived growth factor induced tenascin-C transcription is phosphoinositide 3-kinase/Akt-dependent and mediated by Ets family transcription factors. J. Cell. Physiol. 206, 718-727. doi: 10.1002/jcp. 20527

Jondeau, G., Boutouyrie, P., Lacolley, P., Laloux, B., Dubourg, O., Bourdarias, J. P., et al. (1999). Central pulse pressure is a major determinant of ascending aorta dilation in Marfan syndrome. Circulation 99, 2677-2681. doi: 10.1161/01.CIR.99.20.2677

Katoh, D., Nagaharu, K., Shimojo, N., Hanamura, N., Yamashita, M., Kozuka, Y., et al. (2013). Binding of alphavbetal and alphavbeta6 integrins to tenascin-C induces epithelial-mesenchymal transition-like change of breast cancer cells. Oncogenesis 2, e65. doi: 10.1038/oncsis.2013.27
Kii, I., Nishiyama, T., Li, M., Matsumoto, K., Saito, M., Amizuka, N., et al. (2010). Incorporation of tenascin- $\mathrm{C}$ into the extracellular matrix by periostin underlies an extracellular meshwork architecture. J. Biol. Chem. 285, 2028-2039. doi: 10.1074/jbc.M109.051961

Kimura, T., Shiraishi, K., Furusho, A., Ito, S., Hirakata, S., Nishida, N., et al. (2014). Tenascin C protects aorta from acute dissection in mice. Sci. Rep. 4:4051. doi: $10.1038 /$ srep04051

Kumar, M. S., and Owens, G. K. (2003). Combinatorial control of smooth musclespecific gene expression. Arterioscler. Thromb. Vasc. Biol. 23, 737-747. doi: 10.1161/01.ATV.0000065197.07635.BA

Kung, C. (2005). A possible unifying principle for mechanosensation. Nature 436, 647-654. doi: 10.1038/nature03896

Lange, K., Kammerer, M., Saupe, F., Hegi, M. E., Grotegut, S., Fluri, E., et al. (2008). Combined lysophosphatidic acid/platelet-derived growth factor signaling triggers glioma cell migration in a tenascin-C microenvironment. Cancer Res. 68, 6942-6952. doi: 10.1158/0008-5472.CAN-08-0347

Lincoln, J., Alfieri, C. M., and Yutzey, K. E. (2004). Development of heart valve leaflets and supporting apparatus in chicken and mouse embryos. Dev. Dyn. 230, 239-250. doi: 10.1002/dvdy.20051

Lincoln, J., Alfieri, C. M., and Yutzey, K. E. (2006a). BMP and FGF regulatory pathways control cell lineage diversification of heart valve precursor cells. Dev. Biol. 292, 290-302. doi: 10.1016/j.ydbio.2005.12.042

Lincoln, J., Lange, A. W., and Yutzey, K. E. (2006b). Hearts and bones: shared regulatory mechanisms in heart valve, cartilage, tendon, and bone development. Dev. Biol. 294, 292-302. doi: 10.1016/j.ydbio.2006.03.027

Lockhart, M., Wirrig, E., Phelps, A., and Wessels, A. (2011). Extracellular matrix and heart development. Birth Defects Res. A Clin. Mol. Teratol. 91, 535-550. doi: 10.1002/bdra. 20810

Lutz, R., Sakai, T., and Chiquet, M. (2010). Pericellular fibronectin is required for RhoA-dependent responses to cyclic strain in fibroblasts. J. Cell Sci. 123, 1511-1521. doi: 10.1242/jcs.060905

Mackey, A. L., Brandstetter, S., Schjerling, P., Bojsen-Moller, J., Qvortrup, K., Pedersen, M. M., et al. (2011). Sequenced response of extracellular matrix deadhesion and fibrotic regulators after muscle damage is involved in protection against future injury in human skeletal muscle. FASEB J. 25, 1943-1959. doi: 10.1096/fi.10-176487

Mackie, E. J., Scott-Burden, T., Hahn, A. W., Kern, F., Bernhardt, J., Regenass, S., et al. (1992). Expression of tenascin by vascular smooth muscle cells. Alterations in hypertensive rats and stimulation by angiotensin II. Am. J. Pathol. 141, 377-388.

Maier, S., Lutz, R., Gelman, L., Sarasa-Renedo, A., Schenk, S., Grashoff, C., et al. (2008). Tenascin-C induction by cyclic strain requires integrin-linked kinase. Biochim. Biophys. Acta 1783, 1150-1162. doi: 10.1016/j.bbamcr.2008. 01.013

Marin, J. L., Muniz, J., Huerta, M., and Trujillo, X. (2003). Folding-unfolding of FN-III domains in tenascin: an elastically coupled two-state system. J. Biomech. 36, 1733-1737. doi: 10.1016/S0021-9290(03)00172-6

Matsumoto, K., Arai, M., Ishihara, N., Ando, A., Inoko, H., and Ikemura, T. (1992). Cluster of fibronectin type III repeats found in the human major histocompatibility complex class III region shows the highest homology with the repeats in an extracellular matrix protein, tenascin. Genomics 12, 485-491. doi: 10.1016/0888-7543(92)90438-X

McCain, M. L., and Parker, K. K. (2011). Mechanotransduction: the role of mechanical stress, myocyte shape, and cytoskeletal architecture on cardiac function. Pflugers Arch. 462, 89-104. doi: 10.1007/s00424-011-0951-4

Mettouchi, A., Cabon, F., Montreau, N., Dejong, V., Vernier, P., Gherzi, R., et al. (1997). The c-Jun-induced transformation process involves complex regulation of tenascin-C expression. Mol. Cell. Biol. 17, 3202-3209.

Midwood, K., Sacre, S., Piccinini, A. M., Inglis, J., Trebaul, A., Chan, E., et al. (2009). Tenascin-C is an endogenous activator of Toll-like receptor 4 that is essential for maintaining inflammation in arthritic joint disease. Nat. Med. 15, 774-780. doi: $10.1038 / \mathrm{nm} .1987$

Midwood, K. S., Hussenet, T., Langlois, B., and Orend, G. (2011). Advances in tenascin-C biology. Cell. Mol. Life Sci. 68, 3175-3199. doi: 10.1007/s00018-0110783-6

Midwood, K. S., Mao, Y., Hsia, H. C., Valenick, L. V., and Schwarzbauer, J. E. (2006). Modulation of cell-fibronectin matrix interactions during tissue repair. J. Investig. Dermatol. Symp. Proc. 11, 73-78. doi: 10.1038/sj.jidsymp.5650005 
Midwood, K. S., and Orend, G. (2009). The role of tenascin-C in tissue injury and tumorigenesis. J. Cell Commun. Signal. 3, 287-310. doi: 10.1007/s12079-0090075-1

Mikic, B., Wong, M., Chiquet, M., and Hunziker, E. B. (2000). Mechanical modulation of tenascin-C and collagen-XII expression during avian synovial joint formation. J. Orthop. Res. 18, 406-415. doi: 10.1002/jor.1100180312

Miralles, F., Posern, G., Zaromytidou, A. I., and Treisman, R. (2003). Actin dynamics control SRF activity by regulation of its coactivator MAL. Cell 113, 329-342. doi: 10.1016/S0092-8674(03)00278-2

Nagaharu, K., Zhang, X., Yoshida, T., Katoh, D., Hanamura, N., Kozuka, Y., et al. (2011). Tenascin C induces epithelial-mesenchymal transition-like change accompanied by SRC activation and focal adhesion kinase phosphorylation in human breast cancer cells. Am. J. Pathol. 178, 754-763. doi: 10.1016/j.ajpath.2010.10.015

Nakajima, Y., and Imanaka-Yoshida, K. (2013). New insights into the developmental mechanisms of coronary vessels and epicardium. Int. Rev. Cell Mol. Biol. 303, 263-317. doi: 10.1016/B978-0-12-407697-6.00007-6

Neidhardt, J., Fehr, S., Kutsche, M., Lohler, J., and Schachner, M. (2003). Tenascin$\mathrm{N}$ : characterization of a novel member of the tenascin family that mediates neurite repulsion from hippocampal explants. Mol. Cell. Neurosci. 23, 193-209. doi: 10.1016/S1044-7431(03)00012-5

Nishioka, T., Onishi, K., Shimojo, N., Nagano, Y., Matsusaka, H., Ikeuchi, M., et al. (2010). Tenascin-C may aggravate left ventricular remodeling and function after myocardial infarction in mice. Am. J. Physiol. Heart Circ. Physiol. 298, H1072-H1078. doi: 10.1152/ajpheart.00255.2009

Norris, R. A., Moreno-Rodriguez, R. A., Sugi, Y., Hoffman, S., Amos, J., Hart, M. M., et al. (2008). Periostin regulates atrioventricular valve maturation. Dev. Biol. 316, 200-213. doi: 10.1016/j.ydbio.2008.01.003

Norris, R. A., Potts, J. D., Yost, M. J., Junor, L., Brooks, T., Tan, H., et al. (2009). Periostin promotes a fibroblastic lineage pathway in atrioventricular valve progenitor cells. Dev. Dyn. 238, 1052-1063. doi: 10.1002/dvdy.21933

Nozato, T., Sato, A., Hirose, S., Hikita, H., Takahashi, A., Endo, H., et al. (2013). Preliminary study of serum tenascin-C levels as a diagnostic or prognostic biomarker of type B acute aortic dissection. Int. J. Cardiol. 168, 4267-4269. doi: 10.1016/j.ijcard.2013.04.211

Oberhauser, A. F., Marszalek, P. E., Erickson, H. P., and Fernandez, J. M. (1998). The molecular elasticity of the extracellular matrix protein tenascin. Nature 393, 181-185. doi: 10.1038/30270

Okamoto, H., and Imanaka-Yoshida, K. (2012). Matricellular proteins: new molecular targets to prevent heart failure. Cardiovasc. Ther. 30, e198-e209. doi: 10.1111/j.1755-5922.2011.00276.x

Orend, G., and Chiquet-Ehrismann, R. (2006). Tenascin-C induced signaling in cancer. Cancer Lett. 244, 143-163. doi: 10.1016/j.canlet.2006. 02.017

Pardo, J. V., Siliciano, J. D., and Craig, S. W. (1983a). A vinculin-containing cortical lattice in skeletal muscle: transverse lattice elements ("costameres") mark sites of attachment between myofibrils and sarcolemma. Proc. Natl. Acad. Sci. U.S.A. 80, 1008-1012. doi: 10.1073/pnas.80.4.1008

Pardo, J. V., Siliciano, J. D., and Craig, S. W. (1983b). Vinculin is a component of an extensive network of myofibril-sarcolemma attachment regions in cardiac muscle fibers. J. Cell Biol. 97, 1081-1088. doi: 10.1083/jcb.97. 4.1081

Person, A. D., Klewer, S. E., and Runyan, R. B. (2005). Cell biology of cardiac cushion development. Int. Rev. Cytol. 243, 287-335. doi: 10.1016/S00747696(05)43005-3

Rathjen, F. G., Wolff, J. M., and Chiquet-Ehrismann, R. (1991). Restrictin: a chick neural extracellular matrix protein involved in cell attachment co-purifies with the cell recognition molecule F11. Development 113, 151-164.

Ridley, A. J., and Hall, A. (1992). The small GTP-binding protein rho regulates the assembly of focal adhesions and actin stress fibers in response to growth factors. Cell 70, 389-399. doi: 10.1016/0092-8674(92)90163-7

Russell, B., Curtis, M. W., Koshman, Y. E., and Samarel, A. M. (2010). Mechanical stress-induced sarcomere assembly for cardiac muscle growth in length and width. J. Mol. Cell. Cardiol. 48, 817-823. doi: 10.1016/j.yjmcc.2010. 02.016

Saga, Y., Yagi, T., Ikawa, Y., Sakakura, T., and Aizawa, S. (1992). Mice develop normally without tenascin. Genes Dev. 6, 1821-1831. doi: 10.1101/gad.6. 10.1821
Sage, E. H., and Bornstein, P. (1991). Extracellular proteins that modulate cellmatrix interactions. SPARC, tenascin, and thrombospondin. J. Biol. Chem. 266, 14831-14834.

Samarel, A. M. (2005). Costameres, focal adhesions, and cardiomyocyte mechanotransduction. Am. J. Physiol. Heart Circ. Physiol. 289, H2291-H2301. doi: 10.1152/ajpheart.00749.2005

Sarasa-Renedo, A., Tunc-Civelek, V., and Chiquet, M. (2006). Role of RhoA/ROCKdependent actin contractility in the induction of tenascin-C by cyclic tensile strain. Exp. Cell Res. 312, 1361-1370. doi: 10.1016/j.yexcr.2005. 12.025

Scharer, C. D., McCabe, C. D., Ali-Seyed, M., Berger, M. F., Bulyk, M. L., and Moreno, C. S. (2009). Genome-wide promoter analysis of the SOX4 transcriptional network in prostate cancer cells. Cancer Res. 69, 709-717. doi: 10.1158/0008-5472.CAN-08-3415

Schild, C., and Trueb, B. (2004). Three members of the connective tissue growth factor family CCN are differentially regulated by mechanical stress. Biochim. Biophys. Acta 1691, 33-40. doi: 10.1016/j.bbamcr.2003.12.001

Sivasankaran, B., Degen, M., Ghaffari, A., Hegi, M. E., Hamou, M. F., Ionescu, M. C., et al. (2009). Tenascin-C is a novel RBPJkappa-induced target gene for Notch signaling in gliomas. Cancer Res. 69, 458-465. doi: 10.1158/0008-5472.CAN$08-2610$

Sugi, Y., and Markwald, R. R. (1996). Formation and early morphogenesis of endocardial endothelial precursor cells and the role of endoderm. Dev. Biol. 175, 66-83. doi: 10.1006/dbio.1996.0096

Sussman, M. A., McCulloch, A., and Borg, T. K. (2002). Dance band on the Titanic: biomechanical signaling in cardiac hypertrophy. Circ. Res. 91, 888-898. doi: 10.1161/01.RES.0000041680.43270.F8

Suzuki, H., Shiba, M., Fujimoto, M., Kawamura, K., Nanpei, M., Tekeuchi, E., et al. (2013). Matricellular protein: a new player in cerebral vasospasm following subarachnoid hemorrhage. Acta Neurochir. Suppl. 115, 213-218. doi: 10.1007/978-3-7091-1192-5_39

Tan, H., Biechler, S., Junor, L., Yost, M. J., Dean, D., Li, J., et al. (2013). Fluid flow forces and rhoA regulate fibrous development of the atrioventricular valves. Dev. Biol. 374, 345-356. doi: 10.1016/j.ydbio.2012.11.023

Trescher, K., Thometich, B., Demyanets, S., Kassal, H., Sedivy, R., Bittner, R., et al. (2013). Type A dissection and chronic dilatation: tenascin- $\mathrm{C}$ as a key factor in destabilization of the aortic wall. Interact. Cardiovasc. Thorac. Surg. 17, 365-370. doi: 10.1093 /icvts/ivt204

Tucker, R. P., and Chiquet-Ehrismann, R. (2009). The regulation of tenascin expression by tissue microenvironments. Biochim. Biophys. Acta 1793, 888-892. doi: 10.1016/j.bbamcr.2008.12.012

Tucker, R. P., Drabikowski, K., Hess, J. F., Ferralli, J., Chiquet-Ehrismann, R., and Adams, J. C. (2006). Phylogenetic analysis of the tenascin gene family: evidence of origin early in the chordate lineage. BMC Evol. Biol. 6:60. doi: 10.1186/14712148-6-60

Udalova, I. A., Ruhmann, M., Thomson, S. J., and Midwood, K. S. (2011). Expression and immune function of tenascin-C. Crit. Rev. Immunol. 31, 115-145. doi: 10.1615/CritRevImmunol.v31.i2.30

Van Obberghen-Schilling, E., Tucker, R. P., Saupe, F., Gasser, I., Cseh, B., and Orend, G. (2011). Fibronectin and tenascin-C: accomplices in vascular morphogenesis during development and tumor growth. Int. J. Dev. Biol. 55, 511-525. doi: $10.1387 / \mathrm{ijdb} .103243$ eo

Wagenseil, J. E., and Mecham, R. P. (2009). Vascular extracellular matrix and arterial mechanics. Physiol. Rev. 89, 957-989. doi: 10.1152/physrev.00041.2008

Wang, J. H., and Thampatty, B. P. (2008). Mechanobiology of adult and stem cells. Int. Rev. Cell Mol. Biol. 271, 301-346. doi: 10.1016/S1937-6448(08)01207-0

Wang, N., Tytell, J. D., and Ingber, D. E. (2009). Mechanotransduction at a distance: mechanically coupling the extracellular matrix with the nucleus. Nat. Rev. Mol. Cell Biol. 10, 75-82. doi: 10.1038/nrm2594

Wang, Y., Ait-Oufella, H., Herbin, O., Bonnin, P., Ramkhelawon, B., Taleb, S., et al. (2010). TGF-beta activity protects against inflammatory aortic aneurysm progression and complications in angiotensin II-infused mice. J. Clin. Invest. 120, 422-432. doi: 10.1172/JCI38136

Webb, C. M., Zaman, G., Mosley, J. R., Tucker, R. P., Lanyon, L. E., and Mackie, E. J. (1997). Expression of tenascin-C in bones responding to mechanical load. J. Bone Miner. Res. 12, 52-58. doi: 10.1359/jbmr.1997.12.1.52

Weber, P., Montag, D., Schachner, M., and Bernhardt, R. R. (1998). Zebrafish tenascin-W, a new member of the tenascin family. J. Neurobiol. 35, 1-16. 
Yamashita, O., Yoshimura, K., Nagasawa, A., Ueda, K., Morikage, N., Ikeda, Y., et al. (2013). Periostin links mechanical strain to inflammation in abdominal aortic aneurysm. PLoS ONE 8:e79753. doi: 10.1371/journal.pone. 0079753

Yang, R., Amir, J., Liu, H., and Chaqour, B. (2008). Mechanical strain activates a program of genes functionally involved in paracrine signaling of angiogenesis. Physiol. Genomics 36, 1-14. doi: 10.1152/physiolgenomics.902 91.2008

Zhang, H. Y., Kluge, M., Timpl, R., Chu, M. L., and Ekblom, P. (1993). The extracellular matrix glycoproteins BM-90 and tenascin are expressed in the mesenchyme at sites of endothelial-mesenchymal conversion in the embryonic mouse heart. Differentiation 52, 211-220. doi: 10.1111/j.1432-0436.1993.tb0 0633.x

Zhao, B., Etter, L., Hinton, R. B. Jr., and Benson, D. W. (2007). BMP and FGF regulatory pathways in semilunar valve precursor cells. Dev. Dyn. 236, 971-980. doi: $10.1002 /$ dvdy.21097
Conflict of Interest Statement: The authors declare that the research was conducted in the absence of any commercial or financial relationships that could be construed as a potential conflict of interest.

Received: 28 April 2014; accepted: 10 July 2014; published online: 29 July 2014. Citation: Imanaka-Yoshida K and Aoki H (2014) Tenascin-C and mechanotransduction in the development and diseases of cardiovascular system. Front. Physiol. 5:283. doi: 10.3389/fphys.2014.00283

This article was submitted to Biophysics, a section of the journal Frontiers in Physiology.

Copyright (c) 2014 Imanaka-Yoshida and Aoki. This is an open-access article distributed under the terms of the Creative Commons Attribution License (CC BY). The use, distribution or reproduction in other forums is permitted, provided the original author(s) or licensor are credited and that the original publication in this journal is cited, in accordance with accepted academic practice. No use, distribution or reproduction is permitted which does not comply with these terms. 